\title{
INDUSTRY 4.0 ROLL-OUT STRATEGY FOR DYNAMIC MINE HEAT LOAD MANAGEMENT
}

\author{
D. Nell ${ }^{1 * \#}$, E.H. Mathews ${ }^{1} \&$ P. Maré ${ }^{1 \dagger}$
}

\section{ARTICLE INFO}

Article details

Presented at the $30^{\text {th }}$ annual conference of the Southern African Institute for Industrial Engineering (SAIIE), held from 30 September - 2 October 2019 in Port Elizabeth, South Africa

Available online 15 Nov 2019

\section{Contact details}

Corresponding author dnell@rems2.com

Author affiliations

1 Faculty of Engineering, NorthWest University, Centre for Research and Continued Engineering Development (CRCEDPretoria), Pretoria, South Africa

\# Author was enrolled as a doctoral student at the North-West University's Centre for Research and Continued Engineering Development (CRCED-Pretoria), Pretoria, South Africa

$\dagger \quad$ Post-doctoral student at the North-West University's Centre for Research and Continued Engineering Development (CRCEDPretoria), Pretoria, South Africa

DOI

http://dx.doi.org/10.7166/30-3-2232
Deep-level mining is under severe financial pressure from several unique challenges. One of these is maintaining acceptable underground temperatures for humans to work in while achieving demanding production targets. As mines regularly reach new depths, additional heat is added to the system, contributing to this problem. Accurate mine heat load studies are therefore required to ensure that heat sources are actively evaluated, managed, and mitigated through adequate cooling practices. However, present heat load models are based on design parameters that cater for worst-case scenarios. Most of these models are also based on outdated empirical data taken at a time when mining differed from the present. Industry 4.0 technologies provide potential optimisation benefits when integrated with new heat load models to ensure effective monitoring, and consequently dynamic management, of heat sources. The roll-out strategy presented in this article will serve as a real alternative to earlier and outdated heat load prediction models.

\section{OPSOMMING}

Diepvlak-mynbou is onder hewige finansiële druk weens verskeie unieke uitdagings. Een van die uitdagings is die handhawing van ondergrondse temperature wat geskik is vir mense om in te werk. Soos wat myne gereeld nuwe dieptes bereik word addisionele hitte tot die stelsel toegevoeg wat die probleem vererger. Akkurate myn hittelas studies is dus nodig om te verseker dat hittebronne deurlopend evalueer, bestuur en getemper word deur voldoende verkoelingspraktyke. Bestaande hittelas modelle is egter gebaseer op ontwerpsparameters wat voorsienning maak vir ergste scenario's. Die meeste van hierdie modelle is ook gebaseer op verouderde empiriese datastelle. Industrie 4.0 tegnologieë bied potensiële optimiseringsvoordele wanneer dit met nuwe hittelas modelle geïntegreer word en kan moontlik doeltreffende monitering, en gevolglik dinamiese bestuur, van hittebronne as gevolg hê. Die implementeringstrategie in hierdie artikel kan as 'n werklike alternatief vir vroeër, verouderde hittelasvoorspelling modelle dien.

\section{INTRODUCTION}

South Africa's gold mining industry is under severe pressure, resulting in a declining production trend, as shown in Figure 1. This decline in production leads to reduced revenue, causing substantial strain on the country's economy, and negatively impacts various downstream activities. 


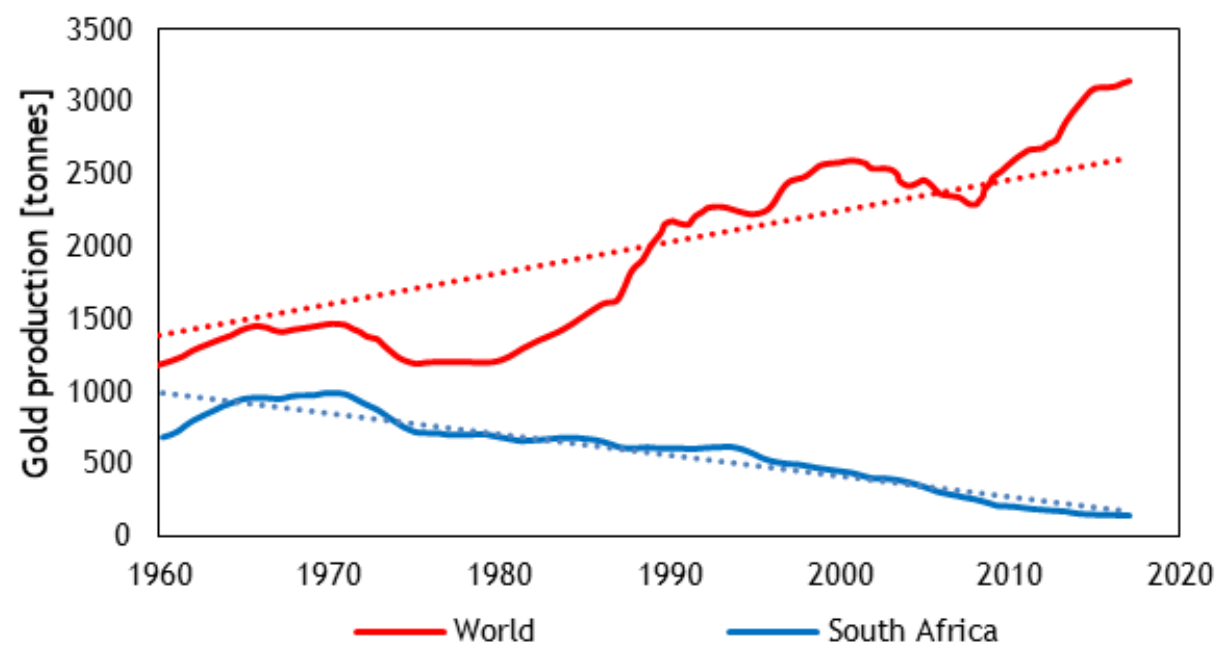

Figure 1: Local vs global gold production since 1960 [1] (see online version for colour)

Despite this negative climate facing the industry, a considerable number of gold ore deposits are still available in South Africa [2]. Figure 2 illustrates that South Africa still holds the number three ranking in mineable gold reserves, which highlights the role yet to be played by this struggling industry.

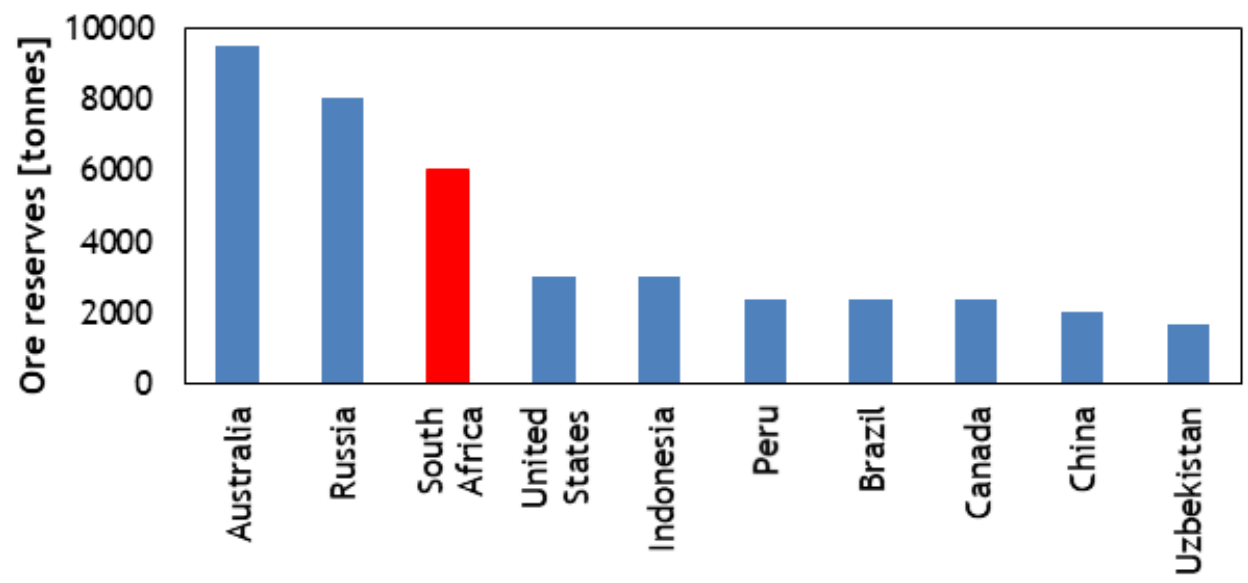

Figure 2: Gold ore reserves per country [2] (see online version for colour)

The South African gold industry is unfortunately strained by a variety of challenges, ranging from technical to socio-economic. One of these challenges is the increasing depth of South African gold mines, which are among the deepest in the world. These increased depths lead to new challenges that directly impact operational efficiency [3].

One such example is that of increased cases of environmental conditions that exceed legal limits and that lead to a direct loss of production [4, 5]. Ensuring that adequate cooling is supplied and used becomes a daily task in most of these mines.

To address and mitigate the rise in heat, heat load studies are performed to ensure that enough cooling is supplied to all active workings and planned workings [6]. At most mining operations these heat load studies are static in nature, and are conducted on an annual basis [7]. These studies are then used during the strategic life-of-mine planning to cater for any required capital expenditure on cooling requirements [6]. 
In an article issued by Deloitte [8] and in a case study performed on a uranium mine [9], it is clear that, with Industry 4.0 on the horizon, the South African mining industry is yet to discover how this new technological front will form part of its day-to-day operations. Facing many social challenges, the adoption of this new technology needs to be a guided process in which the value is realised down to the level of the miner. This will ensure that these technological advances serve as a real alternative to earlier and outdated approaches.

To guide this integration process of new technological advances, a model tailored for the mining industry with regard to ventilation needs to be implemented [10]. One such approach will be that of a data-information-knowledge-wisdom (DIKW) model, as illustrated in Figure 3.

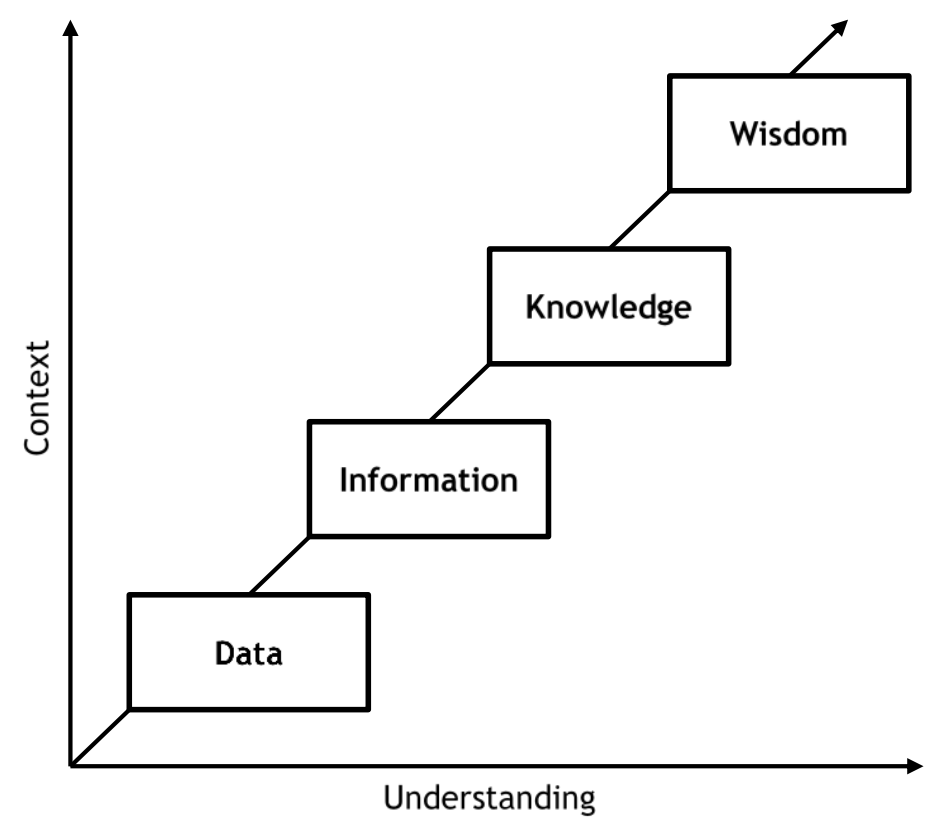

Figure 3: DIKW model [11, 12]

Figure 3 highlights that, to understand fully and appreciate the complete context of a problem, data needs to be translated into wisdom, which will deliver actionable steps to address the problem.

In a study conducted by Pretorius et al. [10], it was proven that significant improvements were realised by implementing an effective DIKW reporting platform on the cooling circuit of a mine. In much the same fashion, substantial benefits can be realised in understanding and reporting on daily heat sources to allow management to have an improved understanding of the nature of the heat sources and how to mitigate their effects.

The methodology in the next section will elaborate on how this model can be used as a roll-out strategy for the mining industry.

\section{METHODOLOGY}

The methodology focused on implementing the DIKW model with the aim of obtaining wisdom from the system that can lead to clear and actionable daily tasks. The method is therefore divided into the four pillars of the DIKW model, highlighted in Figure 3 [12].

\subsection{Data}

A wide variety of technologies is available on the market that is specifically designed to monitor/analyse the ventilation network of a complex system such as a mine. These technologies assist to monitor the system continuously, leading to an improved understanding of how various subsystems interact with one another and which systems are sensitive to specific changes. 
To understand where these technologies need to be implemented, it is important first to understand the basic ventilation network layout of a mine. Figure 4 illustrates such a layout, indicating the location of bulk air coolers (BACs) and return airways (RAWs).

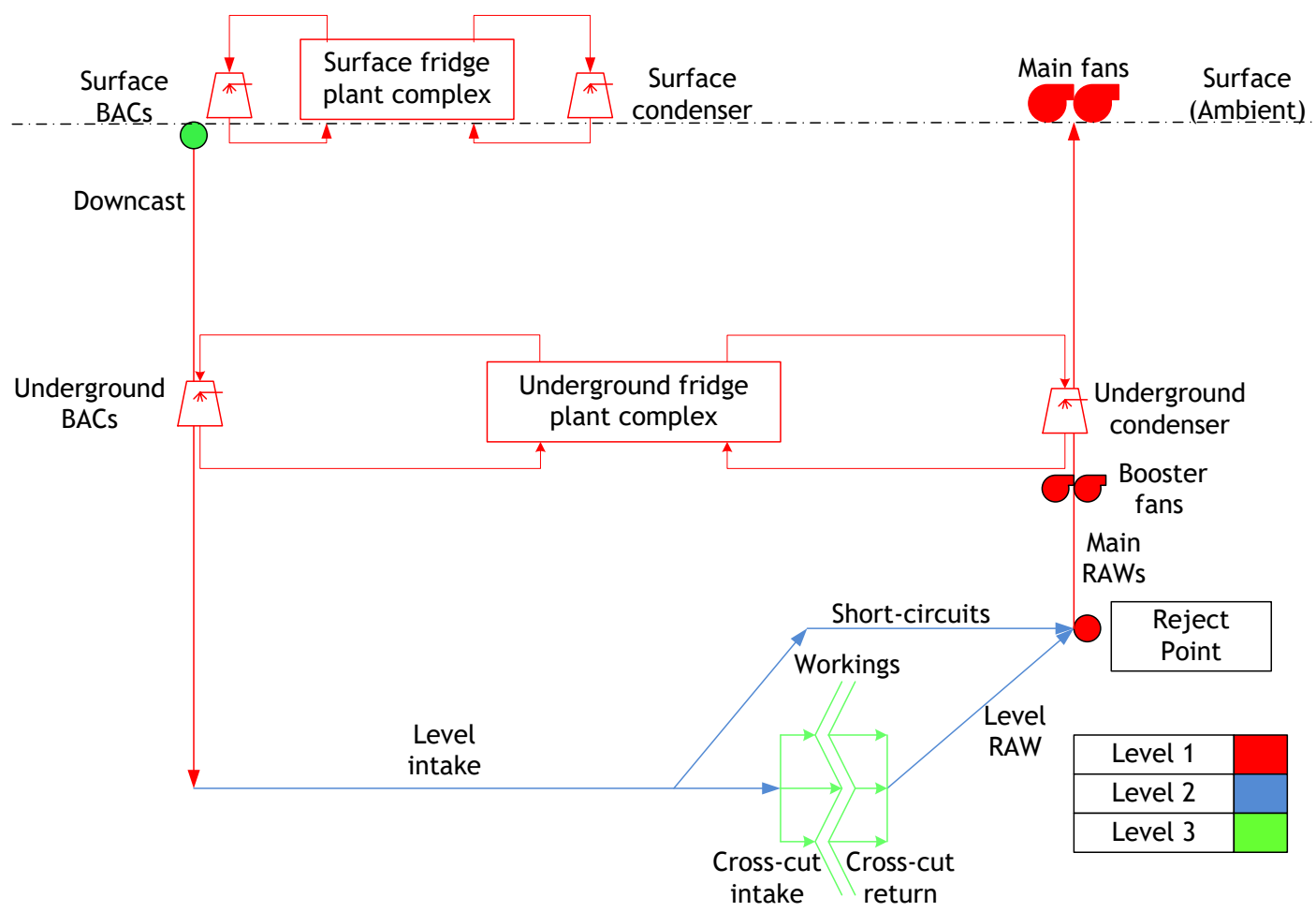

Figure 4: Basic mine ventilation flow diagram [13] (see online version for colour)

From Figure 4 it is evident that numerous components play a role in the ventilation network of a mine. The figure also shows that the heat pickup from the shaft inlet (green dot) to the point of reject (red dot) is essentially the heat experienced by the employees in the working area (also known as 'stopes').

Collecting data at different levels of detail for the various components will lead to improved insight. Monitoring these components will enable effective daily network analysis. These various levels of detail are summarised below in Table 1, and illustrated in Figure 4 above.

Table 1: Data acquisition detail level

\begin{tabular}{|l|l|l|}
\hline Level & Description & Data Points \\
\hline $\begin{array}{l}\text { Level } \\
1\end{array}$ & $\begin{array}{l}\text { Aims at holistically evaluating the mine. It gives valuable insight into } \\
\text { global problems and highlights system constraints, such as inadequate } \\
\text { cooling infrastructure. This data level approach can, therefore, be } \\
\text { implemented to verify that the current infrastructure is adequate. } \\
\text { This will also give valuable insight into the thermodynamic damping } \\
\text { effect (thermal flywheel) and the expected response rate of such } \\
\text { damping. }\end{array}$ & $\begin{array}{l}\text { Ambient air conditions, } \\
\text { fridge plants, BACs, main } \\
\text { return airway, intakes } \\
\text { airways and main fans }\end{array}$ \\
\hline $\begin{array}{l}\text { Level } \\
2\end{array}$ & $\begin{array}{l}\text { Focuses on specific mining levels. This approach is specifically useful } \\
\text { to determine how the intensity of mining processes is distributed, and } \\
\text { where additional infrastructure needs to be introduced. Applying this } \\
\text { level of data collection will highlight places with sub-standard supply } \\
\text { conditions. }\end{array}$ & $\begin{array}{l}\text { Level returns, level } \\
\text { intakes, level-specific } \\
\text { cooling }\end{array}$ \\
\hline $\begin{array}{l}\text { Level } \\
3\end{array}$ & $\begin{array}{l}\text { Focuses on specific workplaces and gives valuable insight into daily } \\
\text { activities and task concentration. This also assists to monitor the } \\
\text { efficiency of ventilation appliances. }\end{array}$ & $\begin{array}{l}\text { Cross-cut intakes/return } \\
\text { airways, fridge plants, } \\
\text { mobile coolers, etc. }\end{array}$ \\
\hline
\end{tabular}

At each of the mentioned data points, forms of energy need to be measured as they cross the specific boundary. In most instances, the main form of energy will be heat transported in the air, and it is crucial that the psychrometric properties of the air are measured [14]. In instances where heat is 
transferred from boundaries other than air (e.g., return water from the BAC), the energy content needs to be monitored.

In most instances, mines implement supervisory control and data acquisition (SCADA) systems without using such systems to their full potential [10]. Ideally, having a mine comply with all three of these levels will enable a precise heat source breakdown, and cater for the specific needs at each working section. However, implementing such a system can be a costly and timeous undertaking, and should rather be phased in gradually.

In cases where such an instrumentation roll-out is restricted by limited capital, key points can be instrumented and used in conjunction with dynamic thermal modelling software [13]. These models bridge the gap between the unknown and the immeasurable, and give valuable insight into daily operational constraints.

As part of this phase-in-plan, it should also be taken into account that, as the level of detail increases, the demand for maintaining and implementing such a system will also increase. Consequently, the required and dedicated manpower should also be allowed for.

\subsection{Information}

As indicated by the second step in the DIKW model, the acquired data needs to be translated into useful information. This is done using an energy balance for the specific levels by accounting for all the forms of energy. This balance will ensure that the energy content in the measurement boundary is accurately characterised. This step has been extensively researched in the past, and various heat load prediction models have been developed [13, 14].

In most instances, mines in South Africa are fairly well-established and, together with the availability of Industry 4.0 technology, these heat sources can be actively measured rather than predicted. Figure 5 elaborates on the various heat sources/sinks in the mining industry.

\subsection{Knowledge}

The daily heat load profile can be constructed automatically to reflect better the dynamic nature of the system. This profile will capture the spike in mining intensity as well as the effect of the ambient conditions.

This is achieved by identifying key performance indicators (KPIs) and translating these parameters into a daily automated reporting system. All relevant role-players receive these reports, and can action tasks based on dynamic system changes. These KPIs will include:

- $\quad$ System resistance curves of the key fan systems to assist in monitoring changes

- $\quad$ Fan use and mechanical condition monitoring

- $\quad$ Air properties of level intakes/returns (quantity and quality)

- Heat load component breakdown to monitor changes in components, such as mechanised equipment, geothermal heat exposure, etc.

- $\quad$ Dynamic heat load balance to track supplied cooling compared with the heat load

\subsection{Wisdom}

The final step is to translate knowledge into actionable wisdom. The derived knowledge will enable wisdom to be applied to the system and the interdependencies of the system to be understood. This will entail some of the following:

- The dynamic heat load profile can be used to structure the planned maintenance of the refrigeration circuits to ensure that the required cooling is always supplied while maintaining infrastructure.

- $\quad$ Planning can be optimised by adding the required infrastructure to address a cooling shortfall and so to achieve the planned reject temperature (return temperature from the workings). The capital and operating costs involved for such infrastructure can be accurately determined from the cooling shortfall to optimise costs.

- $\quad$ From the dynamic heat load profile, the current cooling infrastructure can also be planned to advance alongside mining activity to prevent a situation where mining exceeds the supply scope of the refrigeration system. 


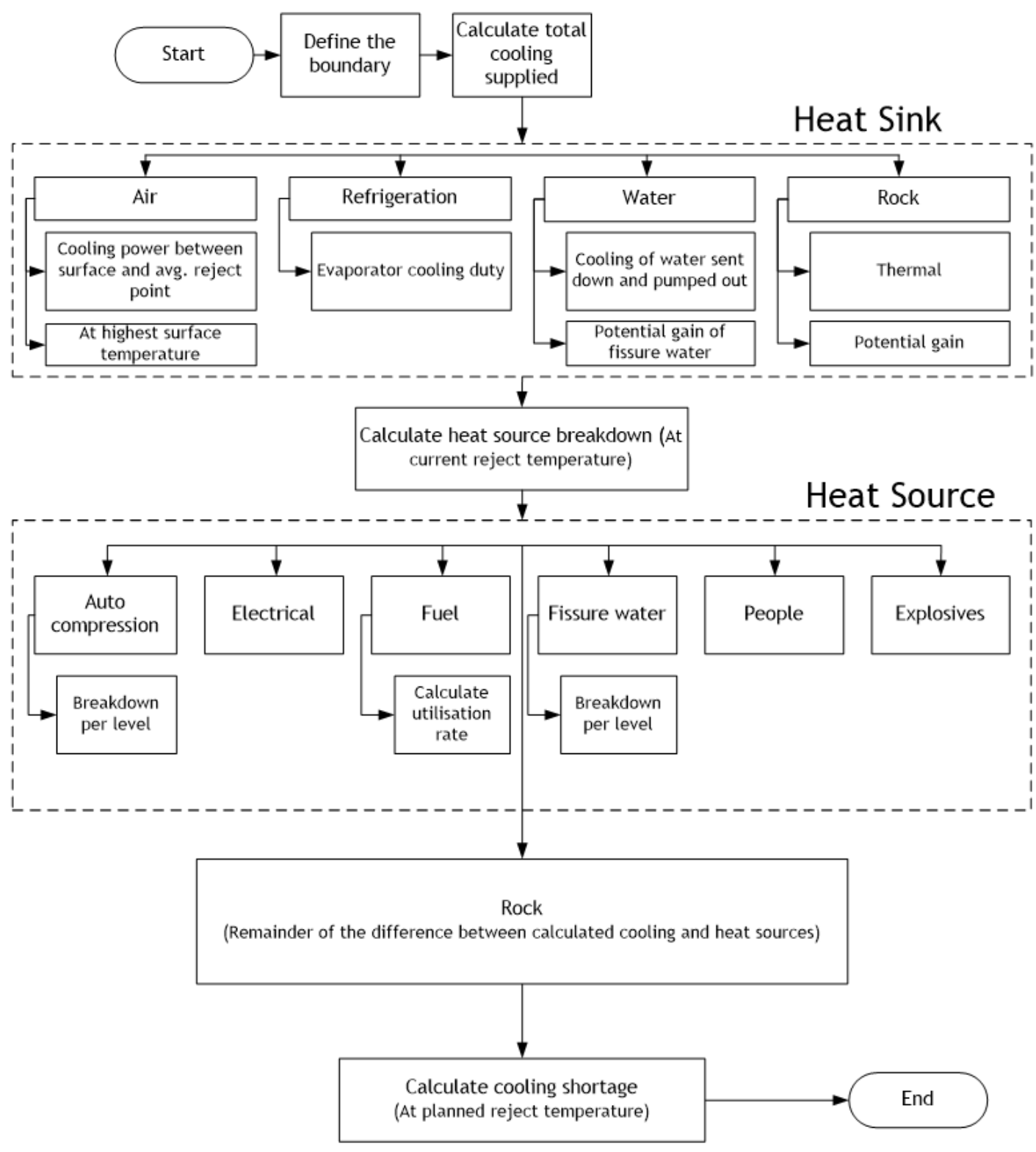

Figure 5: Heat load energy balance approach [14-16]

- The profiles will give insight into over-concentrated mining activity, and assist the manager in distributing these activities more effectively, leading to reduced concentration-induced heat spikes throughout the mine.

- $\quad$ Problem identification will be accelerated greatly through active monitoring. In cases where fall-of-ground, ventilation appliance damage, or any other form of ventilation alteration occurs, the daily monitoring will enable a quick response to these occurrences.

The system architecture described will form the backbone of implementing a ventilation-on-demand system. This will be the final optimisation step in the mine of the future to ensure that localised mining begins at optimal efficiency levels.

\section{RESULTS \& DISCUSSION}

The mine under investigation has partially adopted Industry 4.0 technologies with the aim of monitoring at a level similar to that of level 1, as discussed in Table 1. The results were therefore 
constructed through recorded data and audited data that were translated into an automatic report that was generated daily. The report could then be sent to all involved parties to inform them of any key system changes. The main findings are shared below, based on the holistic energy balance approach.

Figure 6 illustrates the daily heat load profile and the supplied cooling. This is illustrated at the current reject temperature of $32.5^{\circ} \mathrm{C}$ wet-bulb.

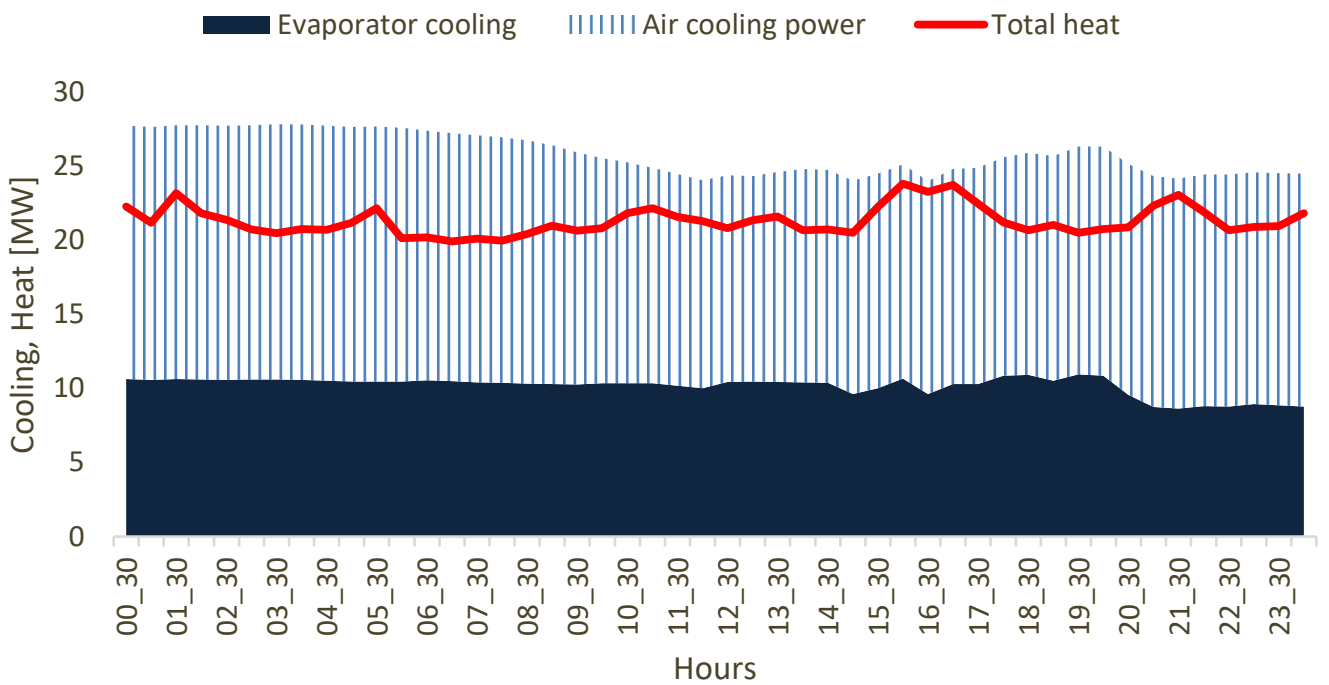

Figure 6: Dynamic heat load - current conditions (see online version for colour)

From Figure 6 it is evident that enough cooling is supplied for the calculated heat load. However, the mine used for this case study is notoriously hot. This serves as a first level indication that, although the secondary cooling infrastructure might be sufficient, large ventilation system inefficiencies exist that need to be investigated.

The next step was plotting the heat load breakdown for the day. This breakdown of all the heat sources and the supplied cooling is monitored and automatically generated. Figure 7 illustrates this breakdown.

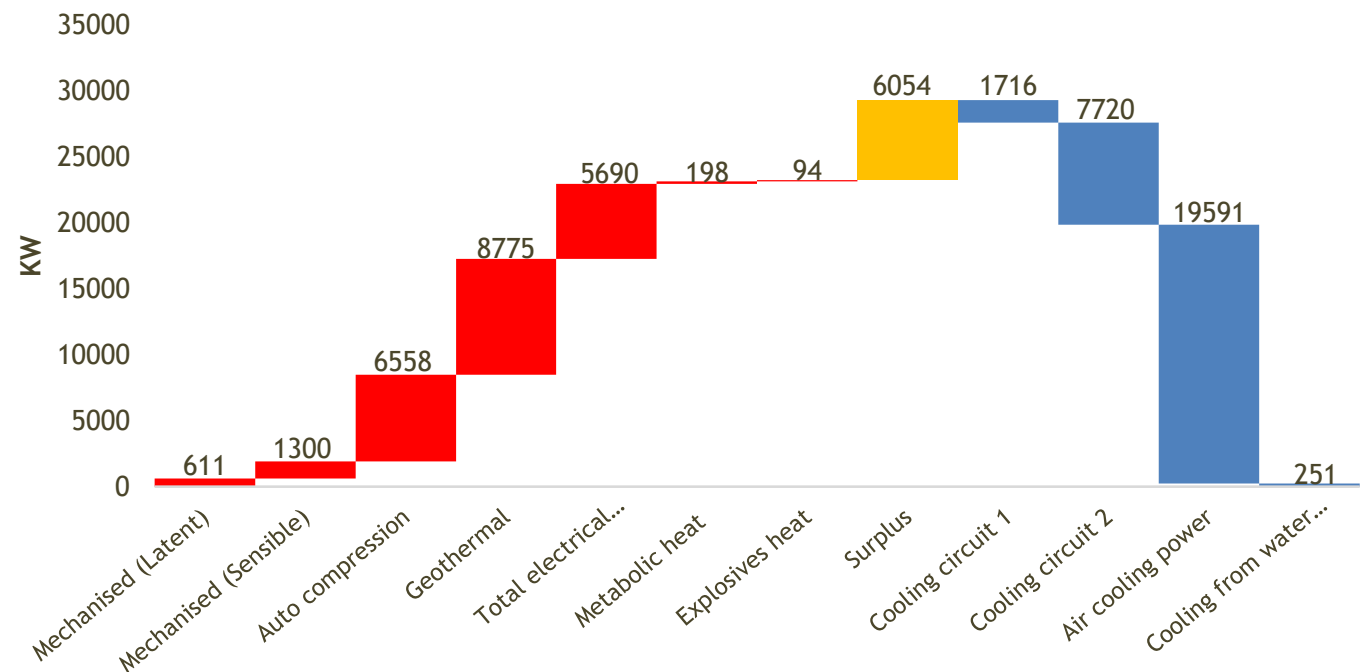

Figure 7: Dynamic heat load breakdown (see online version for colour) 
In Figure 7 the breakdown of each source can be seen and compared on a daily basis to evaluate system changes. The surplus cooling supplied can be interpreted as the system inefficiency, which amounts to about 70 per cent of supplied cooling. This inefficiency consists of a combination of air leakages, or the positional inefficiency of secondary cooling units.

Monitoring equipment was also fitted to crucial equipment to indicate any system changes that might give rise to a change in the mine's heat load. Figure 8 illustrates the system characteristic curve of the surface fan.

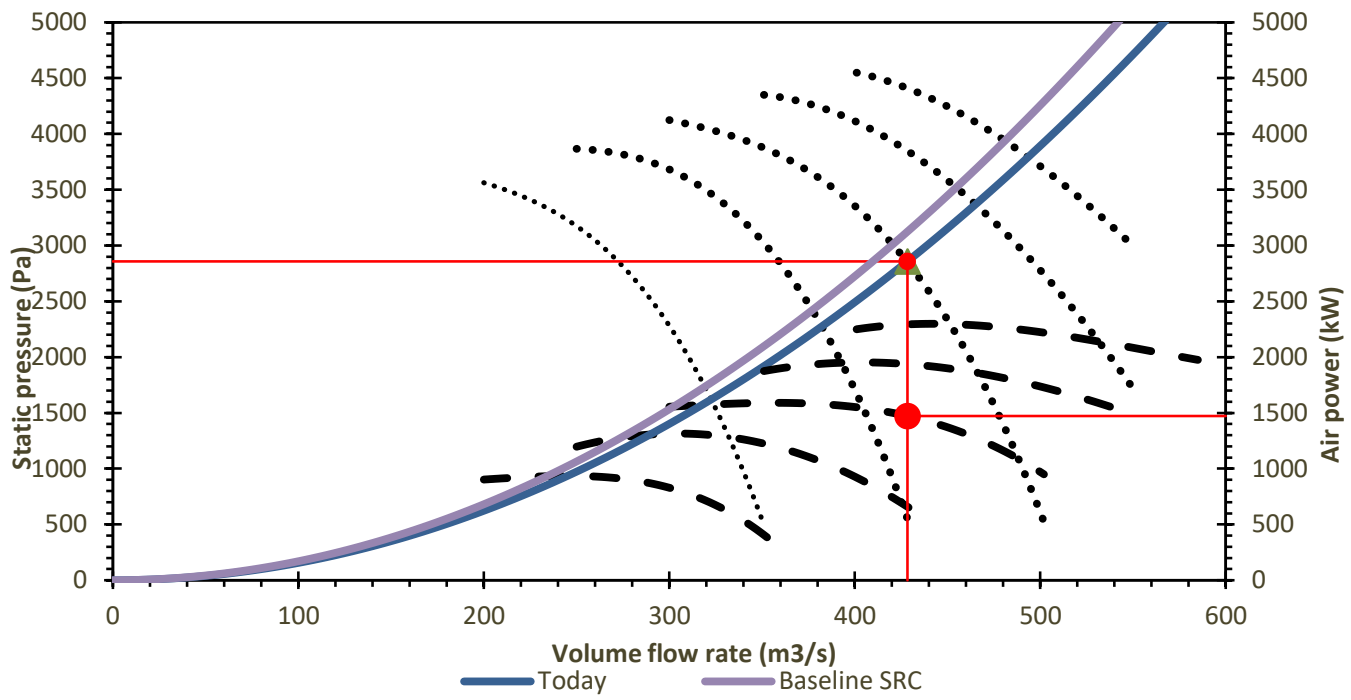

Figure 8: Dynamic surface fan system characteristic curve (see online version for colour)

Monitoring key infrastructure through the information shown in Figure 8 allows the ventilation engineer to understand better the performance of such components, and to detect and quantify any changes occurring in the system. The resistance improvement was the result of key system changes made; these can be seen in Figure 8 by the movement of the blue system resistance line.

Currently, Industry 4.0 technology is still being phased in, and level 2 and level 3 data are planned for the new financial year, which will enable evaluation in more detail. This will highlight problematic areas and give valuable insight into the dynamic nature of the system and the various interdependencies.

\section{CONCLUSION}

Introducing Industry 4.0 technology to mine ventilation will greatly assist the evaluation of the dynamic nature of mines' thermodynamics. It is important, however, that this roll-out is planned and structured in accordance with a DIKW model approach, which has proven in the past to have substantial benefits.

From this approach, the key components of a mine - such as various heat sources - can be easily and frequently evaluated. This will lead to an improved understanding of such heat sources, and whether cooling strategies are effectively applied.

This study has highlighted the need for the use of Industry 4.0 technology to monitor heat load, and has illustrated that data can be translated into wisdom by evaluating the dynamic nature of the daily heat load profiles.

\section{REFERENCES}

[1] Chamber of Mines 2017. Mine SA 2017 Facts \& Figures Pocketbook, Chamb. Mines.

[2] Janisch, P. R. 1986. Gold in South Africa, J. S. Afr. Ins. Min. Met., vol. 86, no. 8, pp. 273-316. 
[3] Neingo, P. N. and Tholana, T. 2016. Trends in productivity in the South African gold mining industry, J. South. African Inst. Min. Metall., vol. 116, no. 2, pp. 283-290.

[4] Section 54s cost SA mines R4.8bn in 2015, and 2016 may be worse - Miningmx, [Online]. Available: https: //www.miningmx.com/opinion/columnists/27866-stoppages-lop-r4-8bn-off-2015-revenue-2016worse/. [Accessed: 06-Jun-2019].

[5] Zondi, M. 2018. Mine Health and Safety Inspectorate - Annual Report 2017/2018.

[6] J. Burrows, R. Hemp, W. Holding, R. . S. 1982. Ventilation and occupational environment engineering in mines, .

[7] Moorecraft, H. 2019. Heat load mangement program.

[8] Deloitte 2018. The Future of Mining in Africa. Navigating a Revolution., pp. 1-24.

[9] Sishi, M. N. 2017. Implementation of Industry 4.0 technologies in the mining industry - a case study By October 2017, no. October.

[10] Pretorius, J. G., Mathews, M. J., Maré, P., Kleingeld, M., and van Rensburg, J. 2019. Implementing a DIKW model on a deep mine cooling system, Int. J. Min. Sci. Technol., vol. 29, no. 2, pp. 319-326.

[11] Rowley, J. 2007. The wisdom hierarchy: representations of the DIKW hierarchy, J. Inf. Sci., vol. 33, no. 2, pp. 163-180.

[12] Ahsan, S. and Shah, A. Data, Information, Knowledge, Wisdom: A Doubly Linked Chain?

[13] McPherson, M. J. 1993. Subsurface ventilation systems, Subsurf. Vent. Environ. Eng., pp. 91-133.

[14] Hemp, R. 1989. Sources of heat in mines, Ventilation and Occupational Environment Engineering in Mines, $3^{\text {rd }}$ Edition, Prof. J.J.L. du Plessis, Mine Ventilation Society of Southg Africa, 2014, 407-439 .

[15] Duckworth, I. J., Mousset-Jones, P., and Advisor, T. 1993. A Heat Balance Study for a Mechanized Cutand-Fill Stope.

[16] Bluhm, S.J., Alexander, N.A., March, T.W., Bottomley, P. \& van Glehn, F. 1986. The Measurement of heat load in Deep level Stope in Klerksdorp Goldfields, Mine Vent. Soc. South Africa, vol. 39, no. 10, pp. 129-140. 